DOI: $10.20472 / E S .2016 .5 .2 .002$

\title{
THE CONTRIBUTION OF EDUCATION TO ECONOMIC GROWTH: EVIDENCE FROM NEPAL
}

\author{
A. Z. NOWAK, GANGADHAR DAHAL
}

\begin{abstract}
:
This paper investigates the long run relationship between education and economic growth in Nepal between 1995 and 2013 through application of Johansen Cointegration technique and OLS. The results from OLS show that secondary and higher education contributes significantly to the Real GDP Per Capita in Nepal. The elementary education also positively influences economic growth but the results are statistically less significant. The cointegration test results confirmed the existence of long run relationship in education (a well-educated human capital) and Real GDP Per Capita. It is therefore, suggested to keep education on top priority in public policies, make serious efforts for Universalization of Primary Education and discourage the drop-out rate at all levels of education to achieve sustained economic growth.
\end{abstract}

\section{Keywords:}

Education, Economic growth, Ordinary Least Squares (OLS)

JEL Classification: 121, 011, C32

\section{Authors:}

A. Z. NOWAK, University of Warsaw, Poland, Email:

GANGADHAR DAHAL, Faculty of management, University of Warsaw, Poland , Email:

dahalgd@hotmail.com

\section{Citation:}

A. Z. NOWAK, GANGADHAR DAHAL (2016). The contribution of education to economic growth: Evidence from Nepal. International Journal of Economic Sciences, Vol. V(2), pp. 22-41., 10.20472/ES.2016.5.2.002 


\subsection{Introduction (including justification)}

Among a few crucial factors of development, education is the most role playing and the crucial factor for the development of a country. Fundamentally, the short-run policy of education tries to address the short-term social and economic goals of the country through awareness programs on safety and health, environment, income generation, balancing standard life and family size management. But in the case of long run, it is directly related to human capital development, factor productivity, economic growth and socio-economic development of the nation. In this research paper, I am trying to focus on the instrumental role of education in poverty reduction, women education and empowerment, environmental protection and sustainability, health promotion, building human capital, enhancing factor productivity and economic growth. Education is both theoretically and empirically proven to be relevant in fighting poverty, creating more opportunities for labor market participation, economic growth, and ultimately socioeconomic development.

Gifted with natural beauty with a huge geographical and biological diversity, Nepal is the developing country situated between two economically giant countries like India and China. Apart from human resources, agriculture, water resources, tourism, forest and biodiversity including rare herbal medicines are the potential sectors of Nepal. Despite these facts, the country is characterized to be an underdeveloped, land-locked and agrobased low-productive economy country as well.

Nepal has recently passed from unilateral monarchy system to multilateral federal system. The country has unutilized or underutilized natural and human resources. Most of the human resources are either unskilled or less skilled due to limited exposure to education and vocational training. Even the educated people have less practical exposure and less entrepreneurship. Thus, Major problems of Nepal are either absolute or related poverty, high population growth rate, greater social fractionalization, underdeveloped financial and other markets, adverse geography, low level of industrialization, low level of living and productivity, large and rapid migration of rural populations to urban areas, lingering colonial impacts such as poor institutions and often external dependence, political instability, and lack of social security and more.

Basically, all these above problems are interrelated with education, education attainment, and research and innovation. In the broad sense, it is also pronounced as the human capital. The first-time economist Theodore Schultz invented the terminology in the 1960s to replicate the value of our human capacities. He believed human capital is like any other type of capital that can be invested in education and training to enhance benefits for an improvement in the quality and level of production. So human capital is most important factor in economic growth and social change Todaro and Smith (2015). Socio-economic development as a process is measured with macroeconomic indicators such as gross 
domestic product, life expectancy, literacy and opportunities for employment in the country. It enforces the new technologies, changing some laws, changing the level of physical environment and ecological changes as well. All these leading to personal freedom, dignity, and more satisfaction.

The concept of social capital draws from various disciplines and sectors has breathed new life into arguments concerning the role and standing of "the social aspects" of development. There is an increasing awareness that community life and institutional quality together could do better to enhance the capacity of societies, manage risk, accept change, and grab opportunities. In the light of the mentioned problems, there is an urgent need of skilled human resources, or educated think tanks, who are able to understand and tackle with the given situation.

In Nepal's history of education, the revolution of 1951 (2007 B.S.) played a milestone role and brought the turning point in the education system of Nepal. The downfall of the Rana regime accompanied in new values not only in the political arena but also in the education sector as well. At that time, Education became a privilege of ruling elite's families during 104 years of Rana regime. It created a situation of changing new thought in Nepal about education in the year 1951 which increased the number of primary schools in the country from 321 in 1951 to over 7250 within two decades of time span. It also created the situation of increasing in the Nepal's Gross Enrolment Rate especially in primary level education from under 1 percent in 1951 to an inspiring 32 percent in 1970 (MoES 1971).

The growth in the number of schools during this period was more a result of the community effort than that of the State. However, things changed in 1971 with the introduction of the New Education System Plan that for the first time in the nation's history comprised the concept of mass education that certainly came as the most important revolving point in the development of Nepal's education sector.

\subsection{Background of the study area}

Increasing the "quantity" of education, however, is but one step in creating an educated, open and justice society. An equally important step is the enhancement of education quality. Nepali students consistently rank poorly in mathematics and science by international standards and have learning outcomes significantly below the targets specified by the national curriculum. Also around 50 percent failure rates in the School Leaving Certificate Exams (exam of grade 10) as the routinely observed reality is the indicative of quality crunch in education (Bhatta 2004, 2005). Coupled with the problem of overall poor education quality is the issue of increasing disparity in education quality across school types such as public and private, location wise such as urban and rural, remote and accessible, and population groups such as males and females, privileged ethnic groups and marginalized ethnic groups. 
Owing to the poor performance of public schools in the board exams than that of private schools, public schools are obliged to enroll learners from the poor segments of the society only through the public schools account for over $75 \%$ of the total student population enrollment. This indicates worsening inequities across different socioeconomic population groups and the quality disparity as the twin problems facing Nepal.

Due to lack of adequate management of capital, technology, and human resources, developing countries often fail to exploit their natural resources. Todaro and Smith (2015) pointed out the lack of skilled manpower in developing economies as one of the constraints for development. Drucker (1974) observed that a country is underdeveloped because it is undermanaged and unexpectedly, management has become a critical constraint in the underdeveloped countries which in turn reminds the concept of World Development Report (2009) that economic growth is seldom balanced. For instance, high poverty, illiteracy, and mortality in some parts of the world set against the prosperity, literacy, and longevity in other parts are challenging the balance and resulting in evergrowing gaps between the developed and developing world to be urgently addressed to protect the enterprises in developing countries until they are ready to compete (World Bank 2009).

The importance of education can be analyzed from women empowerment point of view as well. Women education is penetratingly associated with the formation of women's identity, decision-making capability, mobility and contribution to the socioeconomic development of household, community, and nation. For decades, in developingpatriarchal countries like Nepal men's preference advocated for women's modest education. Hence, how especially education empowers women by enhancing their active participation in the sustainable socioeconomic growth and human capital development (by delaying marriage, managing family-size, increasing gross family income and escalating literacy rate) needs to be studied. Education is fundamental to promote agency, which expresses the capacity of rural poor to escape from poverty and hunger with their own power. An educated is more likely to find a job, but has also, ceteris paribus, a capacity to use more rationally the resources he or she owns. Educated and informed people have more probability to select valuable objectives in life, such as having stable access to food for their household. Even in this argument, there is a gender factor (Sen, 1999). According to still Sen (1999), "female literacy is unambiguous and statistically significant reducing the impact on under-five mortalities, even after controlling for male literacy."

Nepal has recently passed from unilateral monarchy system to multilateral federal system. The country has unutilized or underutilized natural and human resources. Most of the human resources are either unskilled or less skilled due to limited exposure to education and vocational training. Even the educated people have less practical exposure and less entrepreneurship. Thus, Major problems of Nepal are either absolute or related 
poverty, high population growth rate, greater social fractionalization, underdeveloped financial and other markets, adverse geography, lower level of industrialization, low level of living and productivity, large and rapid migration of rural populations to urban areas, existence of colonial impacts such as not only poor institutions but also often external dependency as well, political instability, and lack of social security and many more.

Basically, all these above problems are interrelated with education, education attainment, and research and innovation. In a broad sense, it is also pronounced as the human capital. Economist Theodore Schultz first used the term in the 1960s to reproduce the value of our human capacities. He believed human capital is like any other type of capital that can be invested in education and training to enhance benefits for an improvement in the quality and level of production.

Socio-economic development as a process is measured with indicators such as GDP, life expectancy, literacy and levels of employment Todaro and Smith (2012). Its causes are new technologies, changes in laws, changes in the physical environment and ecological changes all leading to personal freedom, dignity and satisfaction.

\subsection{Rational and objectives of the study}

The main objective of this study is to analyze the contribution of education to the socioeconomic development of Nepal. The specific objectives in compliance with the main objective are as follows

1. To establish the relation between education (Primary education, Secondary education, tertiary and higher education) with GDP.

2. To identify the level of contribution of different level of education to the country's economy.

3. To check either there is a long run relationship of education with economic growth or not.

4. To draw implications for education and socio-economic development policies of Nepal

\subsection{Research Hypothesis:}

To fulfill above objectives of the study, following three hypotheses in the research area have been formulated:

1. HOa: Primary education has the significant effect on economic growth in Nepal.

2. HOb: Secondary education has significant effect economic growth in Nepal

3. HOc: Tertiary and higher education have significant role in economic growth of Nepal 
4. HOd: There is existence of long run relationship in education (a well-educated human capital) and GDP Per Capita

\subsection{Conceptual Framework (1a and 1b)}

There are two conceptual frameworks. Conceptual framework 1a. shows that there are three independent variables primary, secondary and territory as well as higher level education are contributing education. Conceptual framework $1 \mathrm{~b}$. try to explain input, impact and outcomes, in input, there is various level of education including essential tools and IT and technology for logistic support for education. In Impact sector economic growth and in outcomes socioeconomic growth and development are taken. Table $1 \mathrm{~b}$ is in the macro-level framework and covered a wide area of socioeconomic development. In lower cycle denotes the public policies to enhance and control various sectors.

\section{Table 1a: general conceptual framework}

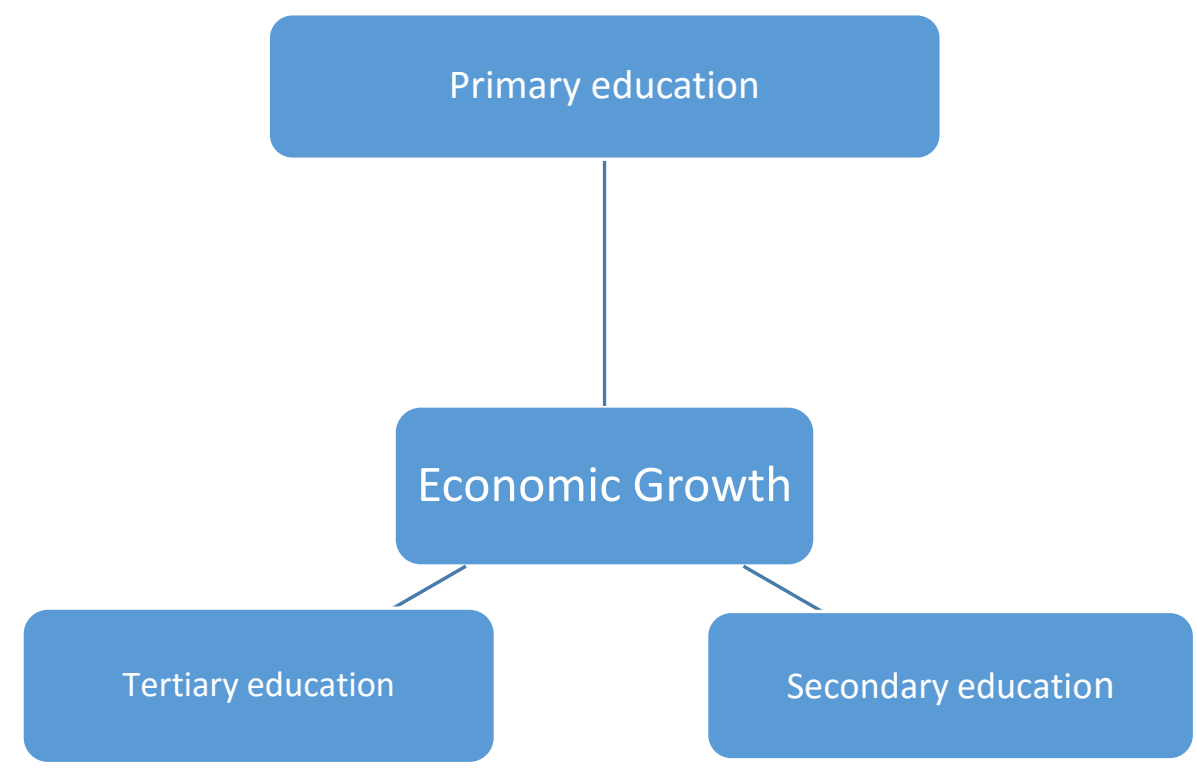




\section{Table 1b: Comprehensive conceptual Framework}
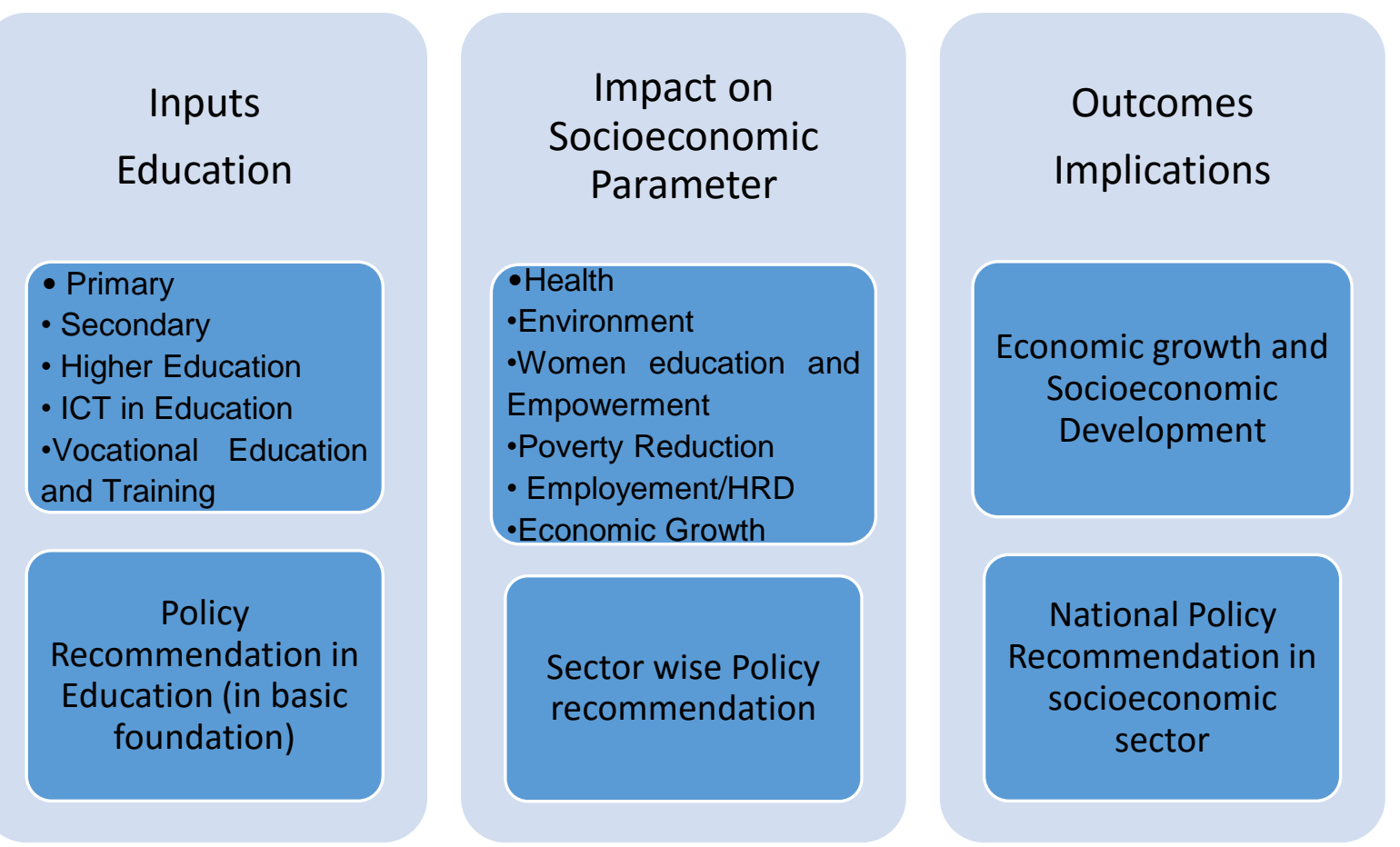

Source: Authors' own conceptual framework of Ph.D. dissertation

\subsection{Literature review with Descriptive analysis and cross country comparison}

Poverty, unstable and undergrowth of GDP, unemployment, and high age dependency ratio are common issues in the most of the developing countries such as Asia, Africa, and Latin America. Data clearly shows that more than 1.3 billion people earn less than US $\$ 1$ per day, people in these countries have been afflicted by poverty and hunger over long periods (Sinnathurai, 2013). He clearly scrutinizes the nexus among poverty, economic growth, employment, and dependency ratio in Asia, Africa, and Latin America and found that poverty, poor and unstable growth of GDP, unemployment, and high age dependency ratio are common issues in the most of the people of developing countries have been afflicted by poverty and hunger over the long period. Similarly, he also displays that lower the labor productivity impacts lower the economic growth and higher the unemployment, and poverty. On the other hand, there is high dependency ratio in a family or in the case of the developing countries leads to lower productivity of such labor force. Thus, this proves the inverse relationship between poverty and employment and also poverty and economic growth.

Schultz (2009) identifies that higher rate of economic growth pays the way the sustained and stable increase in productive capacity, employment opportunities with rising productivity are generated in the economy. That's why this empowers the country to 
absorb more employees in the production and allied activities and thereby decreasing the unemployment rate. These conditions help including poor people in the industrial activities and thus, are benefitted in turning productive labor force finally helping to standardize their lifestyle.

Hawkes \& Ugur (2012) have come up with the ideas of human capital has a wide range of benefits for individual, society and the economy as a whole. In other words, education in terms of personal health, lowering crime rates and environmental protection is the key determinant of economic growth and development. These perceived concepts tie in with the focus of policy on the Millennium Development Goal as the key factors in sustained economic development (UN, 2000). The study has a finding that the countries with higher growth rates are likely to experience a more rapid reduction in poverty. Using provincelevel panel data, this has been demonstrated to hold for Kazakhstan where it was found that inequality declined slightly over the recent high-growth period (1998-2003) accompanied by the reduction in poverty gap and severity. Hawkes \& Ugur (2012) add growth reduces poverty by leading to increased employment and higher real wages. It has further been shown in their study that provinces (regions) of Kazakhstan that received higher expenditure on social sectors experienced a larger decline in poverty indicating a need for sustained, increasing expenditure for the social sectors, more so in the poorer provinces, possibly through additional support from the national government.

A study by Afzalet et al (2012) analyzes the relationship between education and economic growth and demonstrates that nations cannot be developed without investing in education perceived as a multidimensional process. It reduces poverty by increasing productivity and hence, the study proves strong linkages between poverty and education, and education and economic growth in turn.

The term human capital was used first used in 1960's and 70's, when Mincer (1958), Goode (1959), Schultz (1961) and Becker (1975) gave different point of view regarding the concept and formation of human capital, though it got importance by the emergence of endogenous growth theory given by Lucas (1988) and Romer (1989, 1990). Mankiw et al. (1992) used human capital in production function to justify higher economic growth from higher investment in human capital. Many kinds of literatures related to this research argued that education is the first step in the path of the development process. It plays a very crucial role in the building of human capabilities and enhancing economic growth in which investors also like to invest due to a stock of human capital. Education is the imperative part of human competency and sovereignty (Sen, 1999). Kim \& TeradaHagiwara (2010) elaborated the importance of well-educated labor force in the diffusion and adoption of new technology and new methods of production as found to have played a crucial role in developing countries like Pakistan, that have a shortage of physical and human capital (HDR, 2001; Adawo, 2011). 
Like many economists, Adiqa (2011) found the key role of higher education in an economy to grow, flourish and expand career opportunities. The study brings into light that first quantity and quality of education affect highly the labor force, governance and the working conditions of most the institutions. Thus, it is not denying that education is the major determinant for developing the climate for investment in human capital stock. The relationship between education and poverty is quite clear; educated people have higher earning potential and are better able to improve the quality of their lives, which means they are less likely to be marginalized within the society at large (UNESCO, 1997).

Wolff \& Gittleman (1993) examine the relation of higher education level with labor productivity index. They have found a high correlation between university enrollment ratio and labor productivity growth. In the case of science and technology education, the study has a finding that the more the scientists and engineers are produced by the universities, the more is the economic growth.

Bloom, Hartley \& Rosovsky (2006) emphasize on the financial returns generated through tax and paid by individuals. Their study has estimated positive impacts of research and innovation through higher education on economic activity, but emphasized more on financial returns and less on educational returns. But, no such research or study seems to have been undertaken to examine the situation in the poor or developing countries.

Using time series data for Pakistan from1960 to 2003, Abbas \&Peck (2007) have estimated the correlation between human capital and economic growth using OLS technique. They view that human capital has been accounted for about 40 percent increase in GDP with an increase of one percent human capital. Therefore, they have suggested that only low/no investment in education may be one of the reasons of low economic growth stemming from low investment in human capital. Thus, it has been concluded that the higher the level of education of the population the lesser will be the number of poor individuals because education impacts knowledge and skills which are supportive in higher wages (Tilak, 1994). In the developing countries, the social returns of primary education are much higher as compared to that of tertiary education and thus, it is found to be linking millennium development goals also.

Many researchers argue that Millennium Development Goals or Universal Primary Education cannot be achieved by only universalizing primary education. Similarly, Njong (2010) have found that the provision of primary education without giving right consideration to secondary and higher education constrains development through the absence of up-to-date curriculum, lack of skills in administrative posts and in management and he has notably shown a linear relationship between education and earnings. Education increases the probability of being employed as better-educated individuals earn considerably more than less-educated in employment. 
Jandhyala \& Tilak, (2006) focus on the sustainable socio-economic development of the society through sustainable education systems. The study points out that only strong and vibrant education system based on sound assumptions and approaches can play the constitutive and instrumental roles in development as it replaces the traditional ways of economic involvement with time relevant ways.

Wedgwood (2005) examine how progress to post-primary education has become limited to those able to supplement education through private means in the areas having better schools. The study has indicated the issues of quality as a major problem that has raised questions of sustainability. It further provides a glimpse that narrow post-primary education system has been a major limitation. For instance, in Tanzania, the secondary education system is not producing enough quality graduates to supply enough primary teachers. Thus, a strong case can be made for public investment in secondary in order to establish a good foundation on which to build quality UPE.

\subsection{Descriptive analysis and cross country comparison}

Figure 1: Human resource development Index (HDR, 2014)

\section{Human Development Index (HDI), HDR 2014}

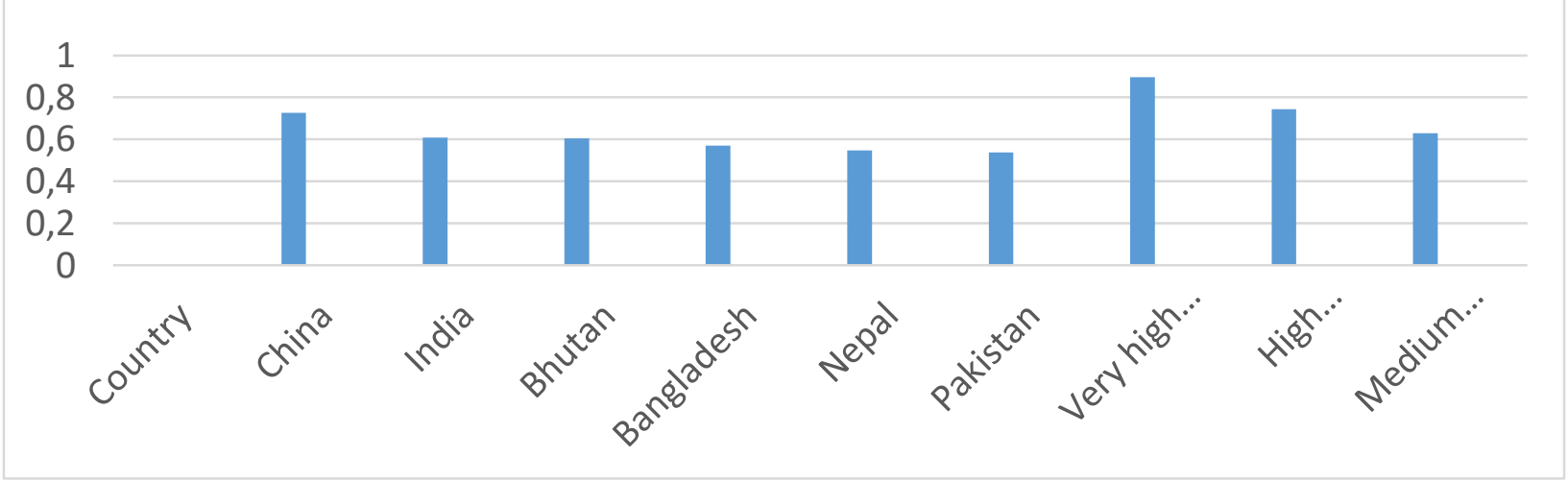

Source HRD report (2015)

The above figure clearly shows that China is doing top most progress in Asian countries which are basically under study in this research paper. India, Bhutan and Bangladesh are also flowing high HDI value. Nepal and Pakistan are also in progress.

\section{Figure 2: Trend of HRI in the selected Asian region}




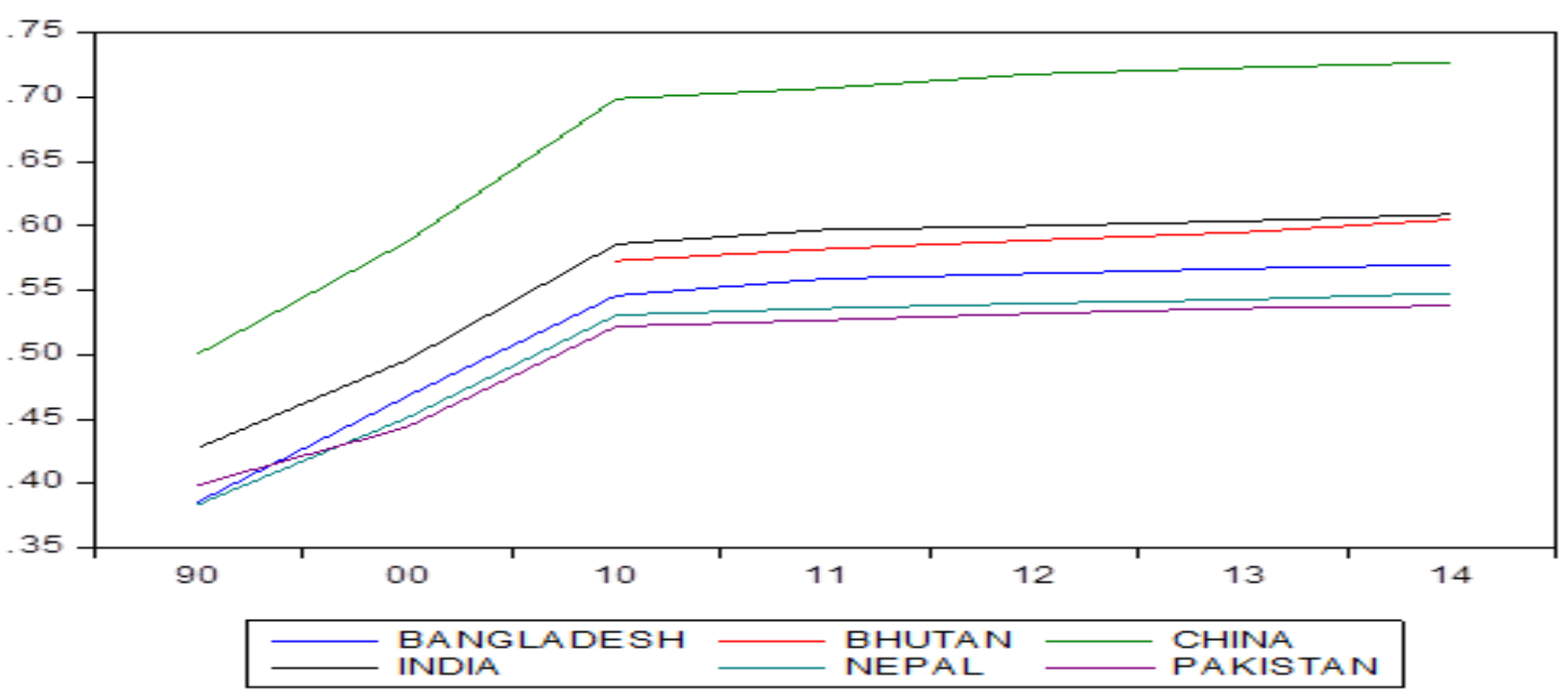

Source HRD report (2015)

The trend of $\mathrm{HDI}$ also proves the above analysis. China is in the top from beginning of the study period. India and Bhutan are in high pace of development and other countries are also in progress but slow rate.

Figure 3: Life expectancy at birth (2014)

\section{Life expectancy at birth, 2014}

Developing countries

Medium human development

Very high human development

$$
\begin{array}{r}
\text { Nepal } \\
\text { Bhutan } \\
\text { China }
\end{array}
$$

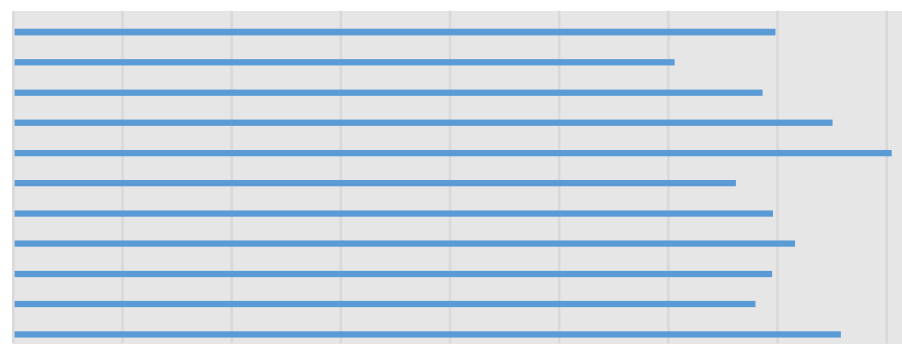

$\begin{array}{llllllllll}0 & 10 & 20 & 30 & 40 & 50 & 60 & 70 & 80 & 90\end{array}$

- Life expectancy at birth (years)

Source world Bank data (2015)

Life expectancy is also important indicator of development and growth. In this case

China is in the front line and other countries are just following. 
Figure 4: Expected years of schooling including Gender prospective

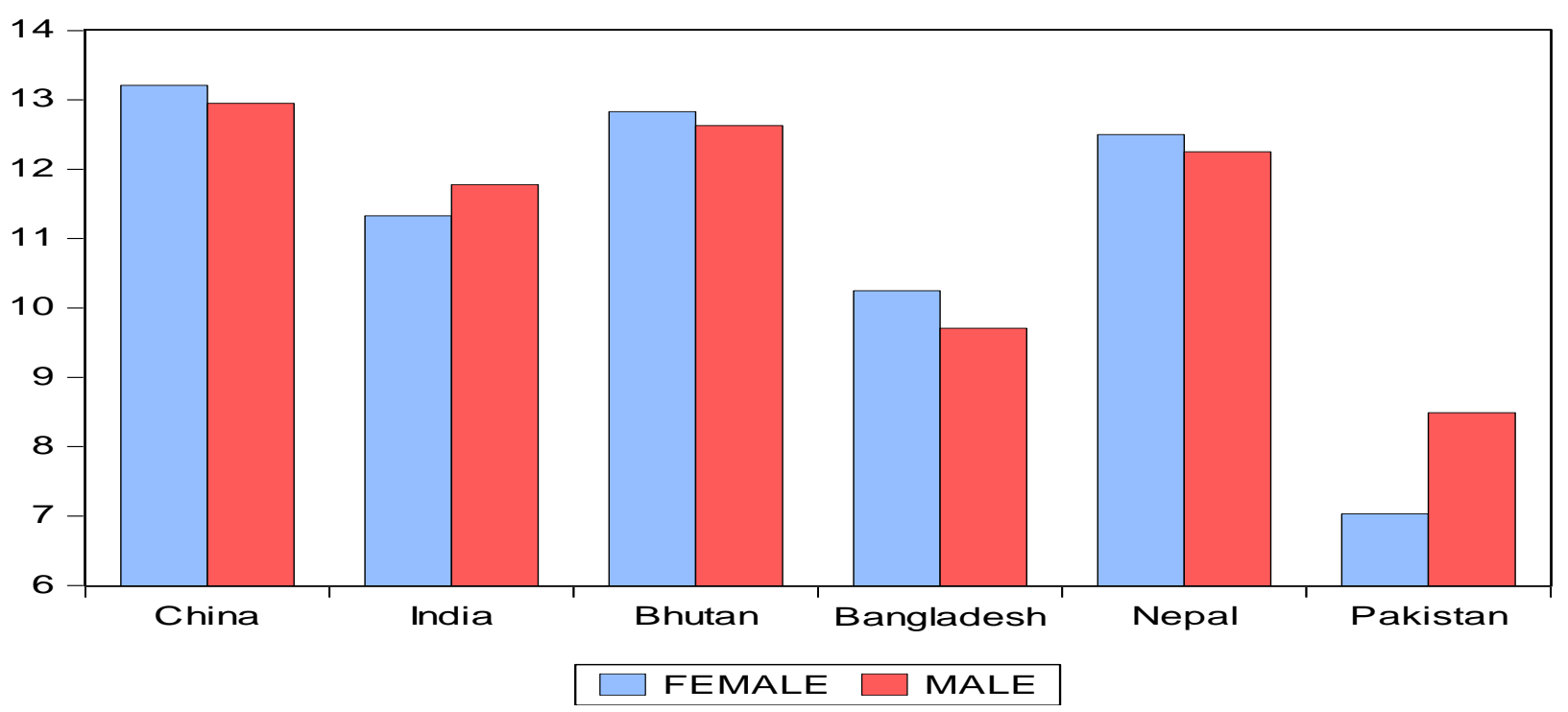

Source world Bank data (2015)

Expected years of schooling means total number of schooling which is highest in China and most important part is that women's schooling is greater than men. Then Bhutan and Nepal in the second category and women's education is also greater than men's education. But India, and Bangladesh are following but Pakistan is in the lowest situation. In addition, women's education is in terrible situation.

Figure 5: Gender development index

Gender Development Index(GDI)

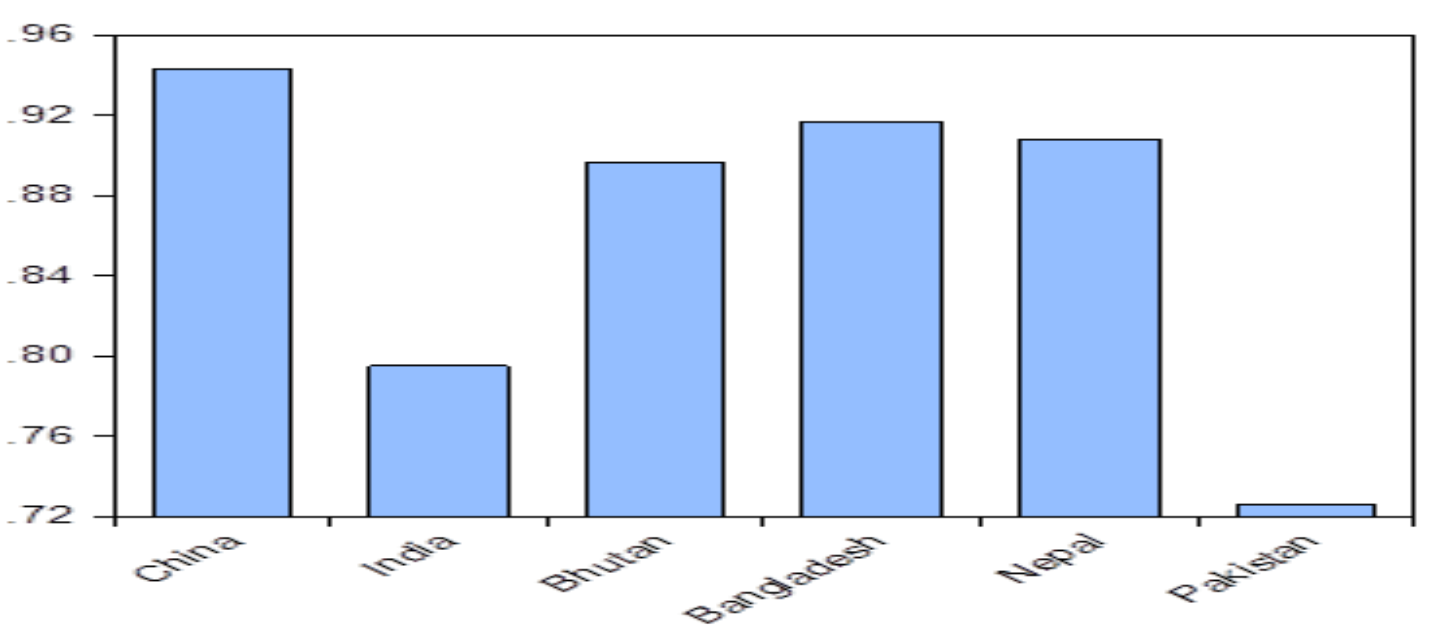

world Bank data (2015)

Gender development index is another important part in this study. In above figure gender development index of China is in top position but Nepal, Bangladesh and 
Bhutan are following. India is in little bit lower size but Pakistan should revise their educational and women empowerment policy. Data shows that there is gender gap.

\subsection{Data and methodology}

In research the reliability of empirical results always depends upon reliable data, data frequency, data span, data sources and the methodology used in the analysis. This section includes data sources and methodology that have been used in the analysis.

\section{Data Sources}

The present study used annual time series data from 1995to 2013 which are taken from world Bank (WB) data source, International Monetary Fund (IMF) and other development reports like World Development Indicators (WDI) and United Nations Development Program (UNDP).

\section{Methodology}

The technique of Ordinary Least Square (OLS by Carl Friedrich Gauss) is used because under certain assumptions namely, the equation to be estimated is linear in parameters, is non-stochastic, has zero mean value, possess equal variance of distribution makes the model a powerful method of regression analysis. The study period of this research is 1995 to $2013 / 14$ on the basis of availability of data. The following equation is used to estimate the model. The technique of Ordinary Least Square (OLS Diagnostic by Carl Friedrich Gauss) is used for the analysis and testing for long run association by Johansson Cointegration is used. The research covers the study period between 1975 to 2014 .

Model specification:

$\mathrm{LNY}=\mathrm{C} 0+\mathrm{C} 1{ }^{*} \mathrm{LNX} 1+\mathrm{C} 2^{*} \mathrm{LNX} 2+\mathrm{C}^{*} \mathrm{LNX} 3+\mathrm{Et}$

Illustration of terminology:

- $\mathrm{Y}=\mathrm{GDP}=$ Gross Domestic Products (dependent variable)

- $\mathrm{X} 1=\mathrm{GERP}=$ Gross Enrollment ratio in Primary level

- $\mathrm{X} 2=\mathrm{GERS}=$ Gross Enrollment ratio in Secondary level

- $\mathrm{X} 3=\mathrm{GERT}=$ Gross Enrollment ratio in Tertiary level

- $\mathrm{Et}=$ Error term

- $\mathrm{C} 0=$ constant coefficient

- $\mathrm{C} 1, \mathrm{C} 2, \mathrm{C} 3$ denote coefficient of respective independent variable

- $\mathrm{LN}=$ natural log 


\subsection{Analysis, result and discussion}

\section{Table 2: Analysis of country base data for Nepal}

Dependent Variable: LNY

Dependent Variable: LNY

Method: Least Squares

Date: 06/02/16 Time: 17:37

Sample: 19752014

Included observations: 40

\begin{tabular}{lrlrr}
\hline \hline \multicolumn{1}{c}{ Variable } & Coefficient & Std. Error & t-Statistic & Prob. \\
\hline \hline LNX1 & 0.391742 & 0.345754 & 1.133005 & 0.2647 \\
LNX2 & 0.713667 & 0.261425 & 2.729910 & 0.0097 \\
LNX3 & 0.114332 & 0.115384 & 0.990889 & 0.3284 \\
C & 17.84562 & 0.974942 & 18.30429 & 0.0000 \\
\hline \hline R-squared & 0.897987 & Mean dependent var & 22.37402 \\
Adjusted R-squared & 0.889486 & S.D. dependent var & 0.502055 \\
S.E. of regression & 0.166901 & Akaike info criterion & -0.648191 \\
Sum squared resid & 1.002815 & Schwarz criterion & -0.479303 \\
Log likelihood & 16.96383 & Hannan-Quinn criter. & -0.587127 \\
F-statistic & 105.6325 & Durbin-Watson stat & 0.257880 \\
Prob(F-statistic) & 0.000000 & & & \\
\hline \hline
\end{tabular}

\section{Interpretations of results}

In the above analysis, the value of $R$ square is 0.8979 that means $89.79 \%$ value of dependent that is GDP $(\mathrm{Y})$ can be explained by independent variables $\mathrm{X} 1, \mathrm{X} 2$ and $\mathrm{X} 3$. Similarly, study shows that there is positive and significant impact independent variables i.e. Enrolment in primary (X1) and secondary (X2) education to GDP (Y). In the same vein, there is the positive impact of Enrolment in tertiary education (X3) in GDP but less significant i.e. only $11.43 \%$. If we use t-statistics, individually only $50 \%$ independent variables are significant according to t- statistics but the probability of F-statistics is less than $5 \%$ level so combined the impact of independent variables $\mathrm{X} 1, \mathrm{X} 2$ and $\mathrm{X} 3$ in the model are significant to GDP $(\mathrm{Y})$ that is the dependent variable.

\section{Table 3: Testing for long run association by Johansson Co-integration}

Sample (adjusted): 19772014

Included observations: 38 after adjustments

Trend assumption: Linear deterministic trend

Series: LNY LNX1 LNX2 LNX3

Lags interval (in first differences): 1 to 1

Unrestricted Cointegration Rank Test (Trace)

\begin{tabular}{ccccc}
\hline \hline $\begin{array}{c}\text { Hypothesized } \\
\text { No. of CE }(\mathrm{s})\end{array}$ & Eigenvalue & $\begin{array}{c}\text { Trace } \\
\text { Statistic }\end{array}$ & $\begin{array}{c}0.05 \\
\text { Critical Value }\end{array}$ & Prob. $^{* *}$ \\
\hline \hline None $^{*}$ & 0.552198 & 49.94236 & 47.85613 & 0.0314
\end{tabular}




$\begin{array}{lllll}\text { At most 1 } & 0.329060 & 19.41297 & 29.79707 & 0.4635 \\ \text { At most 2 } & 0.103125 & 4.248092 & 15.49471 & 0.8825 \\ \text { At most 3 } & 0.002949 & 0.112229 & 3.841466 & 0.7376\end{array}$

Trace test indicates 1 cointegrating eqn(s) at the 0.05 level

* denotes rejection of the hypothesis at the 0.05 level

${ }^{* *}$ MacKinnon-Haug-Michelis (1999) p-values

Unrestricted Cointegration Rank Test (Maximum Eigenvalue)

\begin{tabular}{ccccc}
\hline \hline $\begin{array}{c}\text { Hypothesized } \\
\text { No. of CE(s) }\end{array}$ & Eigenvalue & $\begin{array}{c}\text { Max-Eigen } \\
\text { Statistic }\end{array}$ & $\begin{array}{c}0.05 \\
\text { Critical Value }\end{array}$ & Prob. $^{* *}$ \\
\hline \hline None ${ }^{*}$ & 0.552198 & 30.52939 & 27.58434 & 0.0203 \\
At most 1 & 0.329060 & 15.16487 & 21.13162 & 0.2775 \\
At most 2 & 0.103125 & 4.135863 & 14.26460 & 0.8447 \\
At most 3 & 0.002949 & 0.112229 & 3.841466 & 0.7376 \\
\hline \hline
\end{tabular}

Max-eigenvalue test indicates 1 cointegrating eqn(s) at the 0.05 level

${ }^{*}$ denotes rejection of the hypothesis at the 0.05 level

${ }^{* *}$ MacKinnon-Haug-Michelis (1999) p-values

Unrestricted Cointegrating Coefficients (normalized by $b^{\prime *} S 11^{*} b=I$ ):

\begin{tabular}{cccc}
\hline \hline LNY & LNX1 & LNX2 & LNX3 \\
5.489139 & -5.507933 & -5.460718 & 0.735103 \\
0.654692 & -14.50321 & 10.08676 & -2.129338 \\
-3.227256 & -2.963753 & 0.084307 & 3.571191 \\
-2.950751 & 1.449618 & 3.078054 & -2.068789 \\
\hline \hline
\end{tabular}

Unrestricted Adjustment Coefficients (alpha):

\begin{tabular}{crrrr}
\hline \hline $\mathrm{D}($ LNY $)$ & -0.006981 & 0.000349 & 0.003718 & -0.000837 \\
$\mathrm{D}($ LNX1) & 0.027643 & 0.017151 & 0.008558 & 0.000961 \\
$\mathrm{D}($ LNX2) & 0.042001 & -0.013879 & 0.005557 & -0.000255 \\
$\mathrm{D}($ LNX3) & 0.047758 & 0.012403 & -0.015570 & -0.003638 \\
\hline \hline
\end{tabular}

1 Cointegrating Equation(s): Log likelihood 252.8989

\begin{tabular}{cccc}
\hline \hline \multicolumn{3}{c}{ Normalized cointegrating coefficients (standard error in parentheses) } \\
LNY & LNX1 & LNX2 & LNX3 \\
1.000000 & -1.003424 & -0.994822 & 0.133919 \\
& $(0.43761)$ & $(0.31701)$ & $(0.13588)$ \\
& & \\
Adjustment coefficients (standard error in parentheses) \\
D(LNY) & -0.038318 \\
& $(0.01968)$ \\
D(LNX1) & 0.151734 \\
& $(0.04888)$ \\
D (LNX2) & 0.230549 \\
& $(0.04691)$ \\
D (LNX3) & 0.262152 \\
& $(0.09285)$ \\
\hline
\end{tabular}




\begin{tabular}{cccc}
2 Cointegrating Equation(s): & Log likelihood & 260.4814 \\
\hline \hline Normalized cointegrating coefficients (standard error in parentheses) \\
LNY & LNX1 & LNX2 & LNX3 \\
1.000000 & 0.000000 & -1.772997 & 0.294584 \\
& & $(0.22374)$ & $(0.16400)$ \\
0.000000 & 1.000000 & -0.775520 & 0.160116 \\
& & $(0.11535)$ & $(0.08455)$ \\
Adjustment coefficients (standard error in parentheses) \\
D(LNY) & -0.038089 & 0.033390 & \\
& $(0.01982)$ & $(0.05561)$ & \\
D(LNX1) & 0.162963 & -0.401001 & \\
& $(0.04628)$ & $(0.12989)$ & \\
D(LNX2) & 0.221463 & -0.030047 & \\
& $(0.04526)$ & $(0.12701)$ & \\
D(LNX3) & 0.270272 & -0.442933 \\
& $(0.09272)$ & $(0.26021)$ \\
\hline \hline
\end{tabular}

3 Cointegrating Equation(s): Log likelihood 262.5493

$\begin{array}{cccc}\begin{array}{c}\text { Normalized cointegrating coefficients (standard error in parentheses) } \\ \text { LNY }\end{array} & \text { LNX1 } & \text { LNX2 } & \text { LNX3 } \\ 1.000000 & 0.000000 & 0.000000 & -0.821671 \\ & & & (0.21856) \\ 0.000000 & 1.000000 & 0.000000 & -0.328140 \\ & & & (0.09751) \\ 0.000000 & 0.000000 & 1.000000 & -0.629586 \\ & & & (0.12793)\end{array}$

Adjustment coefficients (standard error in parentheses)

$\begin{array}{llrr}\mathrm{D}(\text { LNY }) & -0.050088 & 0.022371 & 0.041951 \\ & (0.02256) & (0.05566) & (0.04042) \\ \mathrm{D}(\text { LNX1) } & 0.135343 & -0.426366 & 0.022773 \\ & (0.05271) & (0.13006) & (0.09445) \\ \mathrm{D}(\text { LNX2) } & 0.203530 & -0.046516 & -0.368882 \\ & (0.05203) & (0.12837) & (0.09323) \\ \mathrm{D}(\mathrm{LNX3}) & 0.320520 & -0.396788 & -0.137000 \\ & (0.10591) & (0.26133) & (0.18978)\end{array}$

\section{Checking Test of Hypothesis}

Table 2 (OLS Diagnostic) demonstrated that all three null hypotheses are approved. The study came to conclusions that primary education has the significant effect on economic growth in Nepal. Similarly, the study also confirmed that secondary education has also the significant effect economic growth of Nepal. Lastly, research outcomes also demonstrate that tertiary and higher education also have a positive and significant role in economic growth in Nepal. 
Table 3 (Johansson Co-integration) shows that there is an existence of the long run relationship in various level of education (a well-educated human capital) and national economy that is GDP Per Capita of the country.

\section{Test of reliability and validity of data and model}

- There is no serial correlation by using Breusch-Godfrey serial test

- There is no heteroscedasticity which is checked by Breusch-Pagan-Godfrey test

- Residuals are normally distributed which is tested by Histogram Normality that is Jarque-Bera test

- There is no multicollinearity which is tested by using VIF test, the VIF value is less than $10 \%$.

\section{Testing of variables and model:}

- Using Augmented Dickey-Fuller (ADF) test shows that all variables are stationary, there is no random walk at certain level, either in no difference, first difference or second difference.

- $\quad$ ADF is used to test all three i.e. intercept, trend and intercept, and none by using automatic selection in Schwarz Info Criterion (SIC) test. It shows the significant results.

- According to Johansson Co-integration there is long run relationship between education and economic growth in Nepal

\subsection{Summary, conclusion and recommendation}

\section{Summary of major findings}

OLS diagnostic shows that there is a significant and crucial role of primary, secondary and tertiary education in economic growth (GDP) of the developing countries like Nepal. If there is $1 \%$ change in primary enrolment rate leads to increase the GDP by $39.17 \%$. Similarly, for secondary education $71.36 \%$ to GDP and by tertiary or higher education by $11.43 \%$ increase in GDP. So research outcomes show that there is a positive and significant role of various level of education to the national economy that is GDP. By using Johansson Co-integration test it is well-known that there is an existence of a long run relationship between the various level of education and GDP of developing countries like Nepal. This result clearly gives the message to the developing countries there is a high contribution of education to economic growth and ultimately socio-economic development of developing countries. 


\section{Conclusion}

This research paper started with the aim of finding the contribution of education in economic growth of Nepal. The results of the research analysis also supported the view that education contributes to economic growth. The results from OLS education at primary, secondary, as well as tertiary and higher level, affect economic growth. It is concluded on the basis of Johansen Cointegration test results that there exists a long-run relationship between education and economic growth. This means that primary as well as secondary level education contribute to Real GDP per Capita in Nepal and similar Asian countries. It is recommended on the basis of the results of this paper is to keep education on top priority in public policies. The government should leave no stone unturned for the Universalization of Primary Education (UPE) as primary education provides input for secondary education and UPE will accelerate the pace of school as well as college enrollment. The drop out at elementary and secondary level should be discouraged and sources of drop out should be explored.

This research clearly shows that there is a crucial role of education in economic growth (say GDP) and socio-economic development of Nepal and many more least developed and developing countries. There is direct and indirect benefit of basic, secondary and tertiary and a higher level of education in job/labor market participation, family income, family size management etc.

\subsection{Recommendation for policy implications}

In the light of the current study, there are some recommendations and developing countries should realize and implement these guidelines for the future betterment of the country. Research demonstrate that every government of developing countries should put education in high priority and time and need based training and other HRD and skilled development program should be launched keeping education on top priority in public policies. School dropout rates in Primary, secondary and tertiary level in developing countries is the chronic problem so government, political parties, civil society and social workers should think what procedure can be used to stop dropout rates. Gender friendly education policy should be initiated by the developing countries like Nepal. More budget should be allocated to education and training programs and budget should be properly utilized. Developing countries should revise their policies regarding education especially in the public sector but in private sectors performance is little better. Research (Various literature reviews) also shows that Vocational education and skill based training have more impact on labor force participation and overall family income these programs should keep in top priority in public policy and planning commission of Nepal should formulate short term and long term policies and should be implemented in given structure and time framework. 


\section{References}

Adawo, M. A. (2011) Has education (human capital) contributed to the economic growth of Nigeria? Journal of Economics and International Finance, 1(3), 46-58

Adiqa, K. (2011) Role of University Education in Poverty Alleviation in Pakistan. Interdisciplinary Journal of Research in Business, 1 (7), 30-38.

Afzal, M., Malik, M.E., Begum, I., Sarwar, K. and Fatima, H. (2012) Relationship among Education, Poverty and Economic Growth in Pakistan: An Econometric Analysis. Journal of Elementary Education, 22, 23-45

Bhatta S. D. (2005) Determinants of student performance in the SLC exams: evidence from surveydata. SLC Study Report \#11. Kathmandu: Education Sector Advisory Team, DANIDA.

Bhatta, S. D. (2004) Disparities in school performance in the SLC exams: an exploratory analysis. Studies in Nepali History and Society 9(2): 293-343.

Bloom,D., Hartley, M. and Rosovsky, A. (2006b) "Beyond Private Gain: The Public Benefits of Higher education.

Drucker, P.F. (1974) Management: Tasks, Responsibilities and Practices. Oxford, London: ButterworthHeinemann.

Hawkes, D. and Ugur, M. (2012) Evidence on the relationship between education, skills and economic growth in low-income countries: A systematic review. London: EPPI-Centre, Social Science Research Unit, Institute of Education, University of London.

HDR (2001) Human Development Report. Making New Technologies Work for Human Development, UNDP.

James, Foreman-Peck ; Qaisar, Abbas ; james, foreman-peck. (2007) The Mincer Human Capital Model in Pakistan: Implications for Education Policy. In: Cardiff Economics Working Papers.RePEc:cdf:wpaper:2007/24.

Kim, Yong Jin; Terada-Hagiwara, Akiko. (2010) A Survey on the Relationship between Education and Growth with Implications for Developing Asia. () Asian Development Bank. http://hdl.handle.net/11540/1586 Kim, Yong Jin; Terada-Hagiwara, Akiko. 2010. A Survey on the Relationship between Education and Growth with Implications for Developing Asia. ( ) Asian Development Bank. http://hdl.handle.net/11540/1586.

Lucas, R. E. (1988) On the mechanics of economic development. Journal of Monetary Economics, 22(1), 3-42.

Mankiw, N.G., Romer, D., Weil, D.N., (1992) A contribution to the empirics of economic growth. Quarterly Journal of Economics 107, 407- 437.

MoES (1971) Basic and primary education plan 1971. Kathmandu: Ministry of education.

Njong, A. M. (2010) The effects of educational attainment on poverty reduction in Cameroon. Journal of Education Administration and Policy Studies 2 (1), 001-008, http://www. academicjournals.org/JEAPS

Roemer, J. E. (1988) Free to lose. Cambridge, M.A.: Harvard University Press. 
Romer,P, M (1990) Endogenous Technological Change (1990). The Journal of Political Economy, Vol. 98, Issue 5, p. S71-S10 1990. Available at SSRN: http://ssrn.com/abstract=1506720

Schults, T. (2009) The Gender and General consensus of the Demographic Transition and Population Policy: An Assessment of the Micro and Macro Linkage. Working paper no. 71, Yale University

Sen, A (1999) Development as Freedom, Alfred A. Knopf, New York.

Sen, Amartya (1999) Development as Freedom. Oxford: Oxford University Press.

Sinnathurai V. (2013) An Empirical Study on the Nexus of Poverty, GDP Growth, Dependency.

Ratio and Employment in Developing Countries. Journal of Competitiveness, Vol. 5, Issue 2, pp. 67-82, Tomas Bata University in Zlin, Faculty od Management and Economics, Zlín, Czech Republic.

Tilak, J. B. G. (2006) Trends in Public Expenditure on Education: A Contrast Between Two Educationally Backward States: Andhra Pradesh and Rajasthan. Journal of Indian School of Political Economy.

Tilak, Jandhyala B. G (1994) Education for Development in Asia. New Delhi: Sage Publications.

Todaro, M. P. and Smith,S. C. ( 2012) Economic Development, 11th ed., New York: Pearson Education.

Todaro, M. P. and Smith,S. C. ( 2015) Economic Development, 12th ed., New York: Pearson Education.

UNESCO (1997) Educating for a Sustainable Future: A Transdisciplinary Vision for Concerted Action.

Wedgwood, R. (2005) Education and Poverty Reduction in Tanzania, UKFIET Oxford Conference on Education and Development. University of Edinburgh.

Wolff, E. \& Gittleman, M. (1993) The Role of Education in Productivity Convergence: Does Higher Education Matter, in A. Szimai, B. van Ark and D. Pilat, ed., 'Explaining Economic Growth', Elsevier Science Publishers, Amsterdam.

World Bank (2009) World Development Report 2009- Reshaping Economic Geography. Washington D.C.: The World Bank. 